\title{
ENZYME LOADING DEPENDENCE OF CELLULOSE HYDROLYSIS OF SUGARCANE BAGASSE
}

\section{Carlos Martín}

Department of Chemistry and Chemical Engineering, University of Matanzas, Matanzas 44740, Cuba / vTI-Institute for Wood Technology and Wood Biology, Hamburg 21031, Germany

George Jackson de Moraes Rocha

Laboratório Nacional de Ciência e Tecnologia do Bioetanol, CP 6192, 13083-970 Campinas - SP, Brasil

Julliana Ribeiro Alves dos Santos, Maria Carolina de Albuquerque Wanderley e Ester Ribeiro Gouveia*

Departamento de Antibióticos, Universidade Federal de Pernambuco, Cidade Universitária, 50670-901 Recife - PE, Brasil

Recebido em 10/1/12; aceito em 2/7/12; publicado na web em 25/9/12

\begin{abstract}
The enzymatic hydrolysis of steam-pretreated sugarcane bagasse, either delignified or non-delignified, was studied as a function of enzyme loading. Hydrolysis experiments were carried out using five enzyme loadings ( 2.5 to $20 \mathrm{FPU} / \mathrm{g}$ cellulose) and the concentration of solids was $2 \%$ for both materials. Alkaline delignification improved cellulose hydrolysis by increasing surface area. For both materials, glucose concentrations increased with enzyme loading. On the other hand, enzyme loadings higher than 15 FPU/g did not result in any increase in the initial rate, since the excess of enzyme adsorbed onto the substrate restricted the diffusion process through the structure.
\end{abstract}

Keywords: sugarcane bagasse; enzymatic hydrolysis; delignification.

\section{INTRODUCTION}

Lignocellulosic bioresources, such as sugarcane bagasse, are the most abundant complex organic materials available on Earth. They constitute the bulk of plant biomass and consist of three main components: cellulose, lignin and hemicelluloses, ${ }^{1,2}$ which are associated with each other. ${ }^{3}$ Currently, there is growing interest in the use of lignocellulosic bioresources, including agro-industrial residues, such as sugarcane bagasse, in a range of different processes. Electricity generation, pulp and paper production, as well as fermentative processes for obtaining ethanol and enzymes are among the most promising industrial uses for sugarcane bagasse. ${ }^{4}$

The production of ethanol from bagasse requires the hydrolysis of the polysaccharide cellulose and hemicelluloses. The hydrolysis can be catalysed by either acids ${ }^{5}$ or cellulolytic enzymes. ${ }^{6,7}$ Great interest is currently focused on enzymatic hydrolysis because it produces better sugar yields and less degradation products than acid hydrolysis. Enzymatic saccharification of cellulose is generally described as a heterogeneous reaction system, in which cellulases in an aqueous environment react with the insoluble, macroscopic and structured cellulose, containing highly ordered and less ordered regions. ${ }^{8}$

Prior to hydrolysis, a pre-treatment should be applied to lignocellulosic materials in order to enhance enzyme access to cellulose macromolecules. ${ }^{9}$ Among the different pre-treatment methods under investigation, steam explosion is one of the most promising. ${ }^{10}$ This process causes hemicellulose solubilisation, lignin transformation due to high temperature, and improves the susceptibility of cellulose to enzymatic hydrolysis. On the other hand, dilute $\mathrm{NaOH}$ treatment of lignocellulosic materials causes swelling, leading to an increase in internal surface area, a decrease in the degree of polymerization and crystallinity, separation of structural linkages between lignin and carbohydrates, and to disruption of the lignin structure. ${ }^{11}$

Increase in cellulase loading, to a certain extent, can enhance the yield and rate of hydrolysis, but would significantly increase the cost of the process. Cellulase loading in hydrolysis can vary over a wide

*e-mail: estergouveia@gmail.com range, depending on the type and concentration of substrates, and on the protocol used. Increasing the substrate concentration normally results in an increase in hydrolysis yield and reaction rate. However, high substrate concentration can cause substrate inhibition. ${ }^{12}$

In this work, the enzymatic hydrolysis of steam-exploded sugarcane bagasse, either delignified or non-delignified, was performed using five enzyme loadings $(2.5 ; 5 ; 10 ; 15$ and $20 \mathrm{FPU} / \mathrm{g}$ cellulose), while the concentration of solids was kept at $2 \%$ for both materials. The aim of this study was to gain a better understanding of the dependence of hydrolysis upon enzyme loading.

\section{EXPERIMENTAL}

\section{Pretreatment}

Pretreatment processes were carried out at sugarcane mills and ethanol distilleries in the Vale do Rosário, Morro Agudo, São Paulo state, Brazil, as follows: in each pretreatment experiment, around $1000 \mathrm{~kg}$ of dry bagasse was loaded into a 5000-L stainless steel reactor (Caldema Equipamentos Industriais, Sertãozinho, São Paulo state, Brazil). The reactor was hermetically sealed and steam was injected up to a pressure of approximately $1.53 \mathrm{MPa}$ (equivalent to $200^{\circ} \mathrm{C}$ was achieved). After 7 min of pressurization, the reactor was suddenly depressurised by an operator standing at a safe distance, and the steam-exploded slurry was discharged into an 8000-L cyclone, and then collected in a cylindrical container. By centrifugation of the slurry at $1100 \mathrm{rpm}$ or $542.1 \mathrm{~g}$ for 10 min in a 100-L semi-industrial centrifuge (Grisanti Máquinas industriais Ltda, Ribeirão Pires, São Paulo state, Brazil), the solid fraction, hereafter referred to as cellulignin, was separated from the liquid fraction, hereafter referred to as hemicellulosic hydrolysate. The cellulignin was thoroughly washed by resuspending it in a previously determined volume of water at $542.1 \mathrm{~g}$ for $10 \mathrm{~min}$ until the yellow colour of the effluent was totally removed.

\section{Delignification and characterization}

A portion of the pretreated material was delignified with $1 \%$ 
(w/V) $\mathrm{NaOH}$ at $100{ }^{\circ} \mathrm{C}$ for $1 \mathrm{~h}$. The steam-exploded sugarcane bagasse contained $49.9 \%$ cellulose, $8.0 \%$ hemicellulose and $34.0 \%$ lignin. ${ }^{13}$

The content of polysaccharides and lignin in the raw, pretreated and delignified materials was determined by two-step analytical acid hydrolysis, according to the analytical procedure recommended by Rocha et al. ${ }^{14}$ and validated for sugarcane bagasse by Gouveia et al. ${ }^{13}$ Polysaccharide content was calculated after the chromatographic quantification of sugars in the hydrolysates, and lignin was determined as the hydrolysis residue.

Scanning electron microscopy (SEM) images were acquired with a JEOL JSM-5900LV instrument operated with $15 \mathrm{kV}$ accelerating voltage, a $16 \mathrm{~cm}$ working distance and detection of secondary electrons. Sample preparation was done by particulate sticking on the sample holder followed by sputtering of a conductive gold layer.

Specific surface areas (in units of $\mathrm{m}^{2} / \mathrm{g}$ ) were determined by application of the Brunauer, Emmet, and Teller (BET) adsorption model with the relative pressure $\mathrm{P} / \mathrm{P}_{0}$ within the range $0.05<\mathrm{P} / \mathrm{P}_{0}<0.2 .{ }^{15}$

\section{Enzymes}

A commercial preparation of cellulases (Celluclast $1.5 \mathrm{~L}$ ) was used. The enzyme activities of Celluclast (42.4 FPU/mL and 21.1 $\mathrm{CBU} / \mathrm{mL}$ ) were determined according to the method described by Ghose. ${ }^{16}$

\section{Enzymatic hydrolysis}

The pretreated solids were mixed with $0.05 \mathrm{M}$ sodium citrate buffer ( $\mathrm{pH} 4.8)$ resulting in a concentration of $2 \%(\mathrm{w} / \mathrm{V})$. Enzyme loadings of 2.5, 5.0, 10.0, 15.0 and $20.0 \mathrm{FPU} / \mathrm{g}$ cellulose were used. The reaction mixtures were incubated at $50{ }^{\circ} \mathrm{C}$ and $150 \mathrm{rpm}$ for 10 h. For monitoring of the hydrolysis reaction, 1-mL samples were taken at regular intervals. The samples were deactivated by increasing the temperature to $76^{\circ} \mathrm{C}$ for $15 \mathrm{~min}$ and filtering through a $0.45 \mu \mathrm{m}$ membrane before HPLC analysis. All the experiments were carried out in duplicate.

\section{Chromatographic analysis}

Glucose and cellobiose were quantified by HPLC (Agilent HP 1100, Germany) on an Aminex HPX-87H ${ }^{+}$(Bio-Rad, Hercules, CA, USA) column at $50{ }^{\circ} \mathrm{C}$, using $5 \mathrm{mM} \mathrm{H}_{2} \mathrm{SO}_{4}$ at a flow rate of $0.6 \mathrm{~mL} /$ min as mobile phase, and detected with an RI-detector (Agilent). All samples were filtered and diluted prior to analysis.

\section{RESULTS AND DISCUSSION}

The effect of the delignification was evident in the chemical composition of the material. Lignin content decreased from $34.0 \%$ in the steam-pretreated bagasse to $3.0 \%$ in the cellulosic pulp obtained after delignification. On the other hand, as a result of the solubilisation of lignin, cellulose content increased from 49.9 to $81.8 \%$. The alkaline treatment also led to a decrease in the content of hemicelluloses from 8.0 to $6.4 \%$.

As can be seen in the SEM images of the materials, the removal of lignin by alkaline delignification led to unpacked fibers with an open structure (Figures 1a and 1b). These fibers are expected to be more accessible to the action of enzymes. The surface area analysis revealed a higher area $\left(1.34 \pm 0.02 \mathrm{~m}^{2} / \mathrm{g}\right)$ for the cellulosic pulp material than for the non-delignified material $\left(1.24 \pm 0.03 \mathrm{~m}^{2} / \mathrm{g}\right)$.

The increase in cellulose content and decrease in lignin content achieved after delignification are expected to lead to an enhancement in the enzymatic convertibility of the cellulosic pulp compared to the (a)

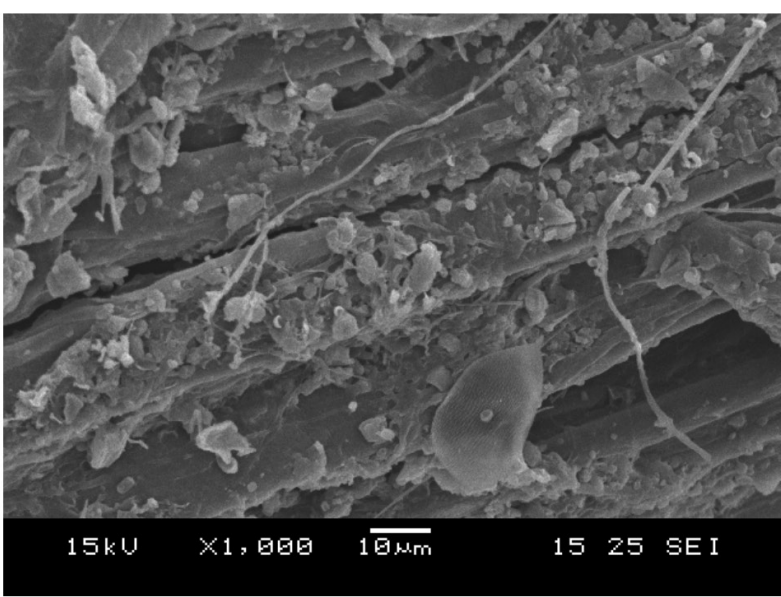

(b)

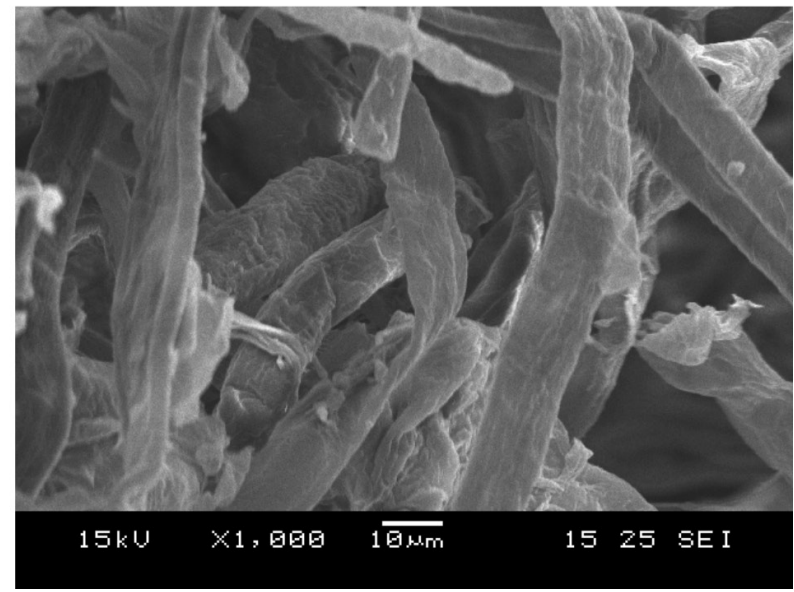

Figure 1. Photomicrography of the non-delignified (a) and delignified (b) materials

non-delignified bagasse. It has previously been reported that $\mathrm{NaOH}$ treatment increased hardwood digestibility from 14 to $55 \%$ concomitantly with a reduction in lignin content from $24-55$ to $20 \% .{ }^{17}$ This was confirmed in our experiments by the higher glucose concentrations achieved in the enzymatic hydrolysis of the delignified material compared to the non-delignified bagasse (Figures $2 \mathrm{a}$ and $2 \mathrm{~b}$ ). This result can be attributed to a higher availability of substrate, since cellulose content was $64 \%$ higher than in the non-delignified material. Another reason is that the delignified material has a lower lignin content, which is known to be detrimental to enzymatic hydrolysis. Lignin forms a protective physical barrier to enzymatic attacks, ${ }^{18}$ and is not extensively removed by steam pretreatment. ${ }^{19}$

In the experiments using 2.5 FPU/g cellulose, glucose concentration in the non-delignified material was only $1.8 \mathrm{~g} / \mathrm{L}$, whereas it was more than five times higher in the delignified material. It is apparent that lignin inhibited the enzymatic hydrolysis of the non-delignified material, and this was probably due to adsorption of cellulases on lignin. According to Esteghlalian et al.,${ }^{20}$ lignin appears to reduce cellulose hydrolysis by non-productively binding cellulolytic enzymes. This result indicates that steam explosion pretreatment alone is not sufficient for enhancing the enzymatic hydrolysis of sugarcane bagasse, and that removal of lignin, for example by alkaline delignification, improves cellulose saccharification.

Cellobiose, a disaccharide formed as result of the incomplete hydrolysis of cellulose, was detected in both hydrolysates. Cellobiose concentration reached $0.9 \mathrm{~g} / \mathrm{L}$, in $6 \mathrm{~h}$ with $15 \mathrm{FPU} / \mathrm{g}$ cellulose (Figure $3 \mathrm{a}$ ), for non-delignified material and reaching around $0.5 \mathrm{~g} / \mathrm{L}$ at $10 \mathrm{~h}$ for all enzyme loadings. Cellobiose accumulation was also observed in the hydrolysis of the delignified material (Figure 3b). An increase 

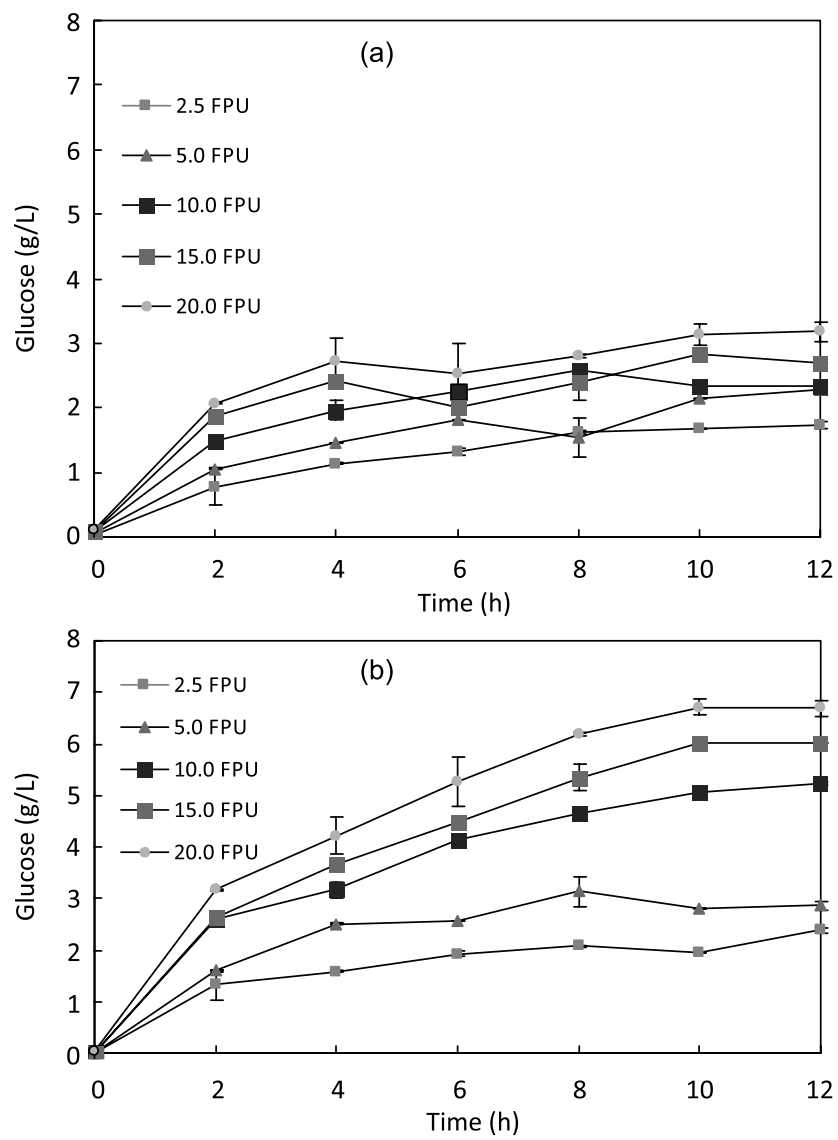

Figure 2. Glucose concentration during the enzymatic hydrolysis of the nondelignified ( $a$ ) and the delignified $(b)$ materials

in cellobiose concentration was noted during the hydrolysis of the delignified material ( 1 to $2.5 \mathrm{~g} / \mathrm{L}$ in $10 \mathrm{~h}$ ). This was probably due to higher cellulose content in this material $(81.8 \%)$.

Initial rates of cellulose hydrolysis were calculated by a linear fit of the data of Figures $2 \mathrm{a}$ and $2 \mathrm{~b}$ for non-delignified and delignified material, respectively. The regression coefficients were all above 0.90 , indicating a good linear fit. Initial rates $\left(\mathrm{v}_{0}\right)$ were higher for the delignified material, and increased steadily with the increase in enzyme loading. However, compared to the experiments with an enzyme loading of $15 \mathrm{FPU} / \mathrm{g}$, no increase in the initial rates was observed for either material when the hydrolysis was performed with a loading of 20 FPU/g cellulose (Figure 4).

The fact that the initial rates did not increase when the enzyme loading was increased from 15 to $20 \mathrm{FPU} / \mathrm{g}$ cellulose can be explained by assuming that the initially adsorbed enzyme on the fiber surface forms just a single layer in such a way that the excess of enzyme would be adsorbed forming additional layers. ${ }^{21}$ This superficially adsorbed enzyme on the first layer of the fiber would play a significant role in the hydrolysis, but will also restrict the diffusion process of enzyme through the structure of the substrate, ${ }^{4}$ and most likely impact the effectiveness of further loaded enzymes. This result is in agreement with a recent paper, reporting that, for different pretreatment methods, glucan digestibility increases with enzyme addition only at a moderate loading. ${ }^{22}$ On the other hand, according to Sun and Chen, ${ }^{12}$ cellulase enzyme loadings in hydrolysis can vary from 7 to $33 \mathrm{FPU} / \mathrm{g}$ cellulose, depending on the type and concentration of substrates.In the hydrolysis of non-delignified material, the conversion of cellulose into glucose was 25.8 and $30.5 \%$ with 15 and $20 \mathrm{FPU} / \mathrm{g}$ cellulose, respectively, in $12 \mathrm{~h}$. Higher conversion was observed in the hydrolysis of delignified material: 34.9 and $38.7 \%$ with 15 and $20 \mathrm{FPU} / \mathrm{g}$
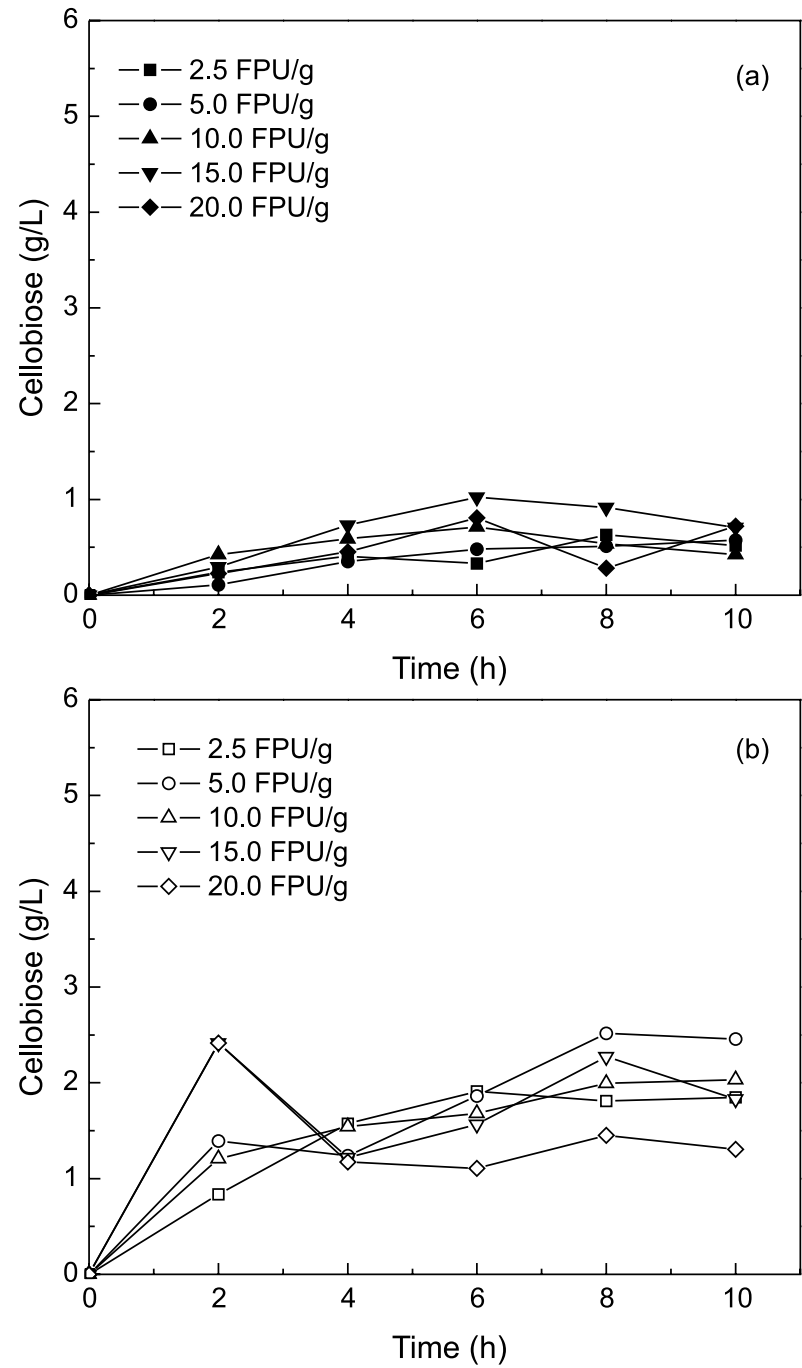

Figure 3. Cellobiose concentration during the enzymatic hydrolysis of the non-delignified ( $a$ ) and the delignified (b) materials

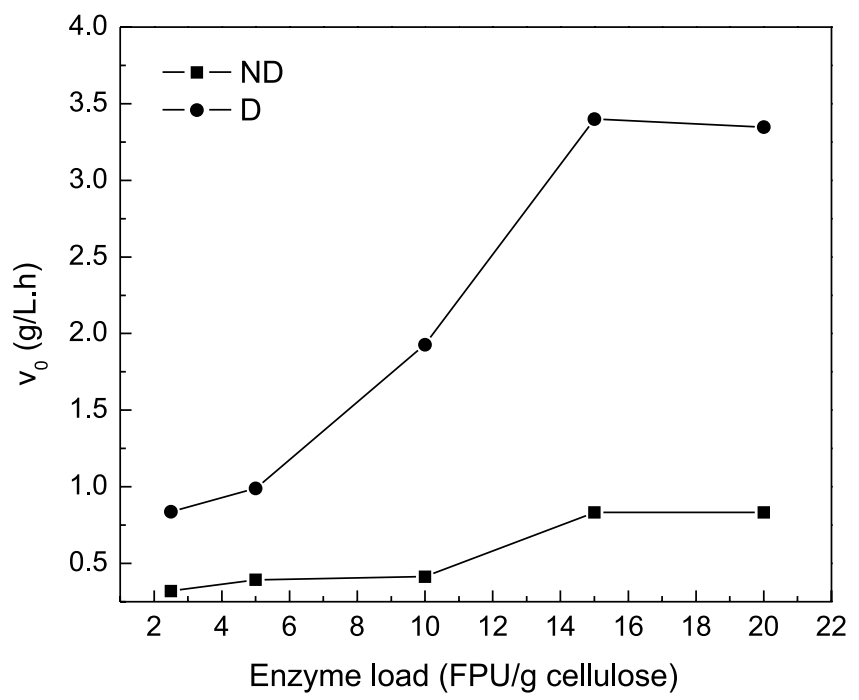

Figure 4. Initial rates of cellulose hydrolysis at different enzyme loadings. $N D$, non-delignified material; $D$, delignified material

cellulose, respectively, for the same period (supplementary material).

Chen et al., ${ }^{23}$ utilizing $20 \mathrm{FPU} / \mathrm{g}$ cellulose, obtained $23.1 \%$ conversion in $12 \mathrm{~h}$ of hydrolysis of Corncob pretreated with $\mathrm{H}_{2} \mathrm{SO}_{4}$ and 
non-delignified material. These authors observed feedback inhibition by cellobiose (3.7 g/L). However, when cellobiase was added, conversion for $12 \mathrm{~h}$ increased to $33.2 \%$. Soares et al., ${ }^{24}$ utilizing around 10 or $20 \mathrm{FPU} / \mathrm{g}$ cellulose, obtained conversions lower than $10 \%$ after $72 \mathrm{~h}$ in the enzymatic hydrolysis of steam pretreated sugarcane bagasse which was unwashed or that had been washed with water or $1 \%$ aqueous $\mathrm{NaOH}$ solution.

Analysis of variance by Origin 6.0 was performed with conversions obtained at $12 \mathrm{~h}$ in the hydrolysis runs with all loadings, when the non-delignified (ND) or delignified (D) material was used. The results utilizing 15 or $20 \mathrm{FPU} / \mathrm{g}$ cellulose were not significantly different for non-delignified (test $\mathrm{F}=7.25 ; \alpha=0.05-95 \%$ confidence) or delignified material (test $\mathrm{F}=18.26 ; \alpha=0.05-95 \%$ confidence). The analysis of variance (ANOVA) indicated that the maximum enzymatic conversion obtained with 15 or $20 \mathrm{FPU} / \mathrm{g}$ cellulose was similar when non-delignified or delignified material was used. These results correspond to the initial rates (Figure 4).

\section{CONCLUSIONS}

The removal of lignin by alkaline delignification led to unpacked fibers and a slight increase in surface area ( $1.24 \pm 0.03$ to $1.34 \pm 0.02$ $\mathrm{m}^{2} / \mathrm{g}$ to), considerably improving cellulose saccharification of steamexploded bagasse (25.8 to $34.5 \%$, with $15 \mathrm{FPU} / \mathrm{g}$ cellulose and 30.5 to $38.7 \%$, with $20 \mathrm{FPU} / \mathrm{g}$ cellulose).

Enzymatic hydrolysis of cellulose consists of three steps: adsorption of cellulase enzymes onto the surface of the cellulose, the biodegradation of cellulose to fermentable sugars, and desorption of cellulase. However, the irreversible adsorption of cellulase on cellulose is partially responsible for its deactivation. ${ }^{12}$ It is likely that reversible adsorption was the factor responsible for higher enzymatic conversion of sugarcane bagasse in relation to results obtained by Soares et al., ${ }^{24}$ when utilizing the same steam pretreated sugarcane bagasse.

The higher cellobiose concentration (around $2 \mathrm{~g} / \mathrm{L}$ ) observed during the hydrolysis of the delignified material did not cause feedback inhibition, since the conversion was $35 \%$ in $10 \mathrm{~h}$, when $15 \mathrm{FPU} / \mathrm{g}$ cellulose was used.

Enzyme loadings higher than $15 \mathrm{FPU} / \mathrm{g}$ cellulose resulted in no significant increase in the initial rate or in enzymatic conversion for ND or D material. It can be concluded that a lower enzyme loading can be used for both materials.

\section{SUPPLEMENTARY MATERIAL}

Available at http://quimicanova.sbq.org.br, in format pdf with free access. Figure 1S - Conversion during the enzymatic hydrolysis of the non-delignified (a) and the delignified (b) materials.

\section{ACKNOWLEDGMENTS}

The authors acknowledge the financial support from CNPq (Conselho Nacional de Desenvolvimento Científico e Tecnológico,
Brasilia DF, Brazil) and FACEPE (Fundação de Amparo à Ciência e Tecnologia do Estado de Pernambuco, Brazil). C. Martín gratefully acknowledges the financial support given by the Alexander von Humboldt Foundation.

\section{REFERENCES}

1. Sjöström, E.; Wood Chemistry: Fundamentals and applications. $2^{\text {nd }}$ ed., Academic Press: San Diego, 1993.

2. Badhan, A. K.; Chadha, B. S.; Kaur, J.; Saini, H. S.; Bhat, M. K.; Bioresour. Technol. 2007, 98, 504.

3. Fengel, D.; Wegener, G.; Wood, chemistry, ultrastructure, reactions, Waster \& Grugter: New York, 1984.

4. Carrillo. F.; Lis, M. J.; Colom, X.; Lopez-Mesas, M.; Valdeperas, J.; Process Biochem. 2005, 40, 3360.

5. Taherzadeh, M. J.; Karimi, K.; Bioresources 2007, 2, 472.

6. Lynd, L. R.; Weimer, P. J.; van Zyl, W. H.; Pretorius, I. S.; Microbiol. Mol. Biol. Rev. 2002, 66, 506.

7. Taherzadeh, M. J.; Karimi, K.; Bioresources 2007, 2, 707.

8. Arantes, V.; Saddler, J. N.; Biotechnol. Biofuels 2010, 3, 4.

9. Yang, B.; Wyman, C. E.; Biof. Bioprod. Biorefin. 2008, $2,26$.

10. Saddler, J. N.; Ramos, L.; Breul, C. Em Bioconversion of forest and agricultural residues; Saddler, I. N., ed.; CAB International: Wallingford, 1993, p. 73-91.

11. Fan, L. T.; Lee, Y. H.; Gharpuray, M. M.; Adv. Biochem. Eng. 1982, 23, 157.

12. Sun, Y.; Cheng, J.; Bioresour. Technol. 2002, 83, 1.

13. Gouveia, E. R.; Nascimento, R. T.; Souto-Maior, A. M.; Rocha, G. J. M.; Quim. Nova. 2009, 32, 1500.

14. Rocha, G. J. M.; Silva, F. T.; Araújo, G. T.; Curvelo, A. A. S.; Resumos do V Brazilian Symposium Proceedings on the Chemistry of Lignin and Other Wood Components, Curitiba, Brasil, 1997.

15. Driemeier, C.; Pimenta, M. T. B.; Rocha, G. J. M.; Oliveira, M. M.; Mello, D. B.; Maziero, P.; Gonçalves, A. R.; Cellulose 2011, 18, 1509.

16. Ghose, T. K.; Pure Appl. Chem. 1987, 59, 257.

17. Kumar, R.; Mago, G.; Balan, V.; Wyman, C. E.; Bioresour. Technol. 2009, 100, 3948.

18. Palonen, H.; Tese de Doutorado, Helsinki University of Technology, Finland, 2004.

19. Ohgren, K.; Bura, R.; Saddler, J.; Zacchi, G.; Bioresour. Technol. 2007, 98, 2503.

20. Esteghlalian, A.; Bilodeau, M.; Mansfield, S. D.; Saddler, J. N.; Biotechnol. Progr. 2001, 17, 1049.

21. Lee, Y. H.; Fan, L. T.; Biotechnol. Bioeng. 1983, 32, 853.

22. Pallapolu, V. R.; Lee, Y. Y.; Garlock, R. J.; Balan, V.; Dale, B. E.; Kim, Y.; Mosier, N. S.; Ladisch, M. R.; Falls, M.; Holtzapple, M. T.; Sierra, R.; Shi, J.; Ebrik, M. A.; Redmond, T.; Yang, B.; Wyman, C. E.; Donohoe, B. S.; Vinzant, T. B.; Elander, R. T.; Hames, B.; Thomas, S.; Warner, R. E.; Bioresour. Technol. 2011, 102, 11115.

23. Chen, M.; Xia, L.; Xue, P.; Int. Biodeter. Biodegr. 2007, 59, 85.

24. Soares, I. B.; Travassos, J. A.; Baudel, H. M.; Benachour, M.; Abreu, C. A. M.; Ind. Crop. Prod. 2011, 33, 670. 


\section{ENZYME LOADING DEPENDENCE OF CELLULOSE HYDROLYSIS OF SUGARCANE BAGASSE}

\section{Carlos Martín}

Department of Chemistry and Chemical Engineering, University of Matanzas, Matanzas 44740, Cuba / vTI-Institute for Wood Technology and Wood Biology, Hamburg 21031, Germany

George Jackson de Moraes Rocha

Laboratório Nacional de Ciência e Tecnologia do Bioetanol, CP 6192, 13083-970 Campinas - SP, Brasil

Julliana Ribeiro Alves dos Santos, Maria Carolina de Albuquerque Wanderley e Ester Ribeiro Gouveia*

Departamento de Antibióticos, Universidade Federal de Pernambuco, Cidade Universitária, 50670-901 Recife - PE, Brasil
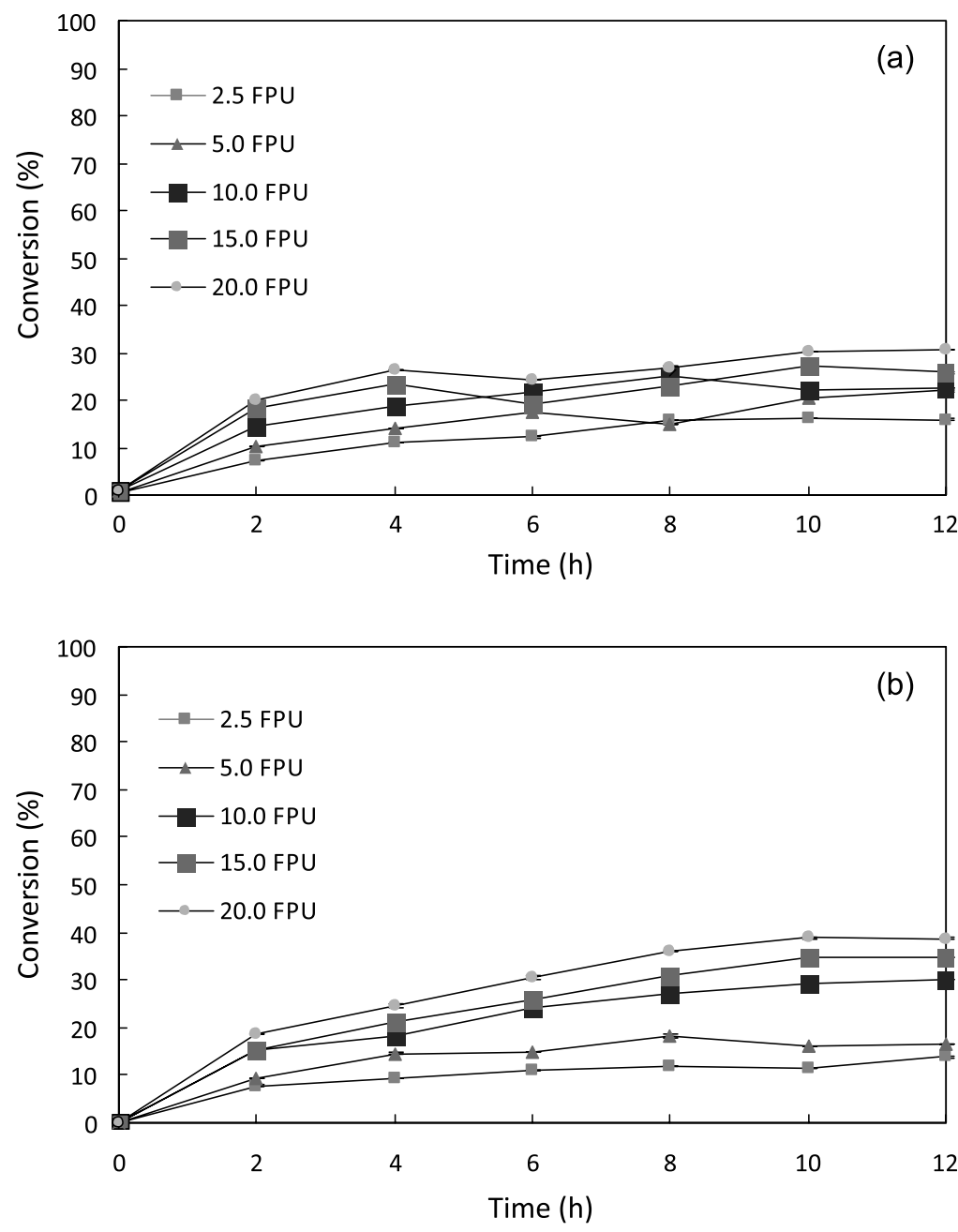

Figure 1S. Conversion during the enzymatic hydrolysis of the non-delignified (a) and the delignified (b) materials 